E-ISSN 2355-3987

www.ijhn.ub.ac.id

Artikel Hasil Penelitian

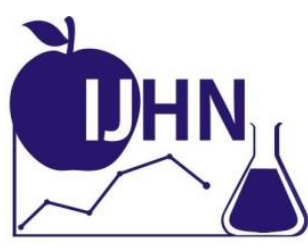

\title{
Konsumsi Fast Food, Soft Drink, Aktivitas Fisik, dan Kejadian Overweight Siswa Sekolah Dasar di Jakarta
}

\author{
Vina Rizky Putri ${ }^{1}$, Dudung Angkasa ${ }^{1 *}$, Rachmanida Nuzrina ${ }^{1}$ \\ Program Studi Ilmu Gizi, Fakultas Ilmu-Ilmu Kesehatan, Universitas Esa Unggul \\ *Alamat korespondensi: dudung.angkasa@esaunggul.ac.id
}

\begin{abstract}
Abstrak
Prevalensi overweight pada anak umur 5-12 tahun di provinsi Jakarta tertinggi (30,1\%, nasional $10,8 \%$ ) Tujuan penelitian ialah 1) menganalisis hubungan konsumsi fast food, soft drink, dan aktivitas fisik (AF) dengan kejadian overweight 2) mengetahui perbedaan asupan, lingkar pinggang (LP) dan total lemak tubuh (TLB) pada anak sekolah dasar. Studi potong lintang dilakukan dengan jumlah responden yang terdiri dari masing-masing 57 anak overweight dan berat normal di sekolah dasar negeri di Jakarta. Konsumsi fast food,soft drink diukur dengan FFQ, asupan energi dan zat gizi makro dengan recall tiga hari tak berturut, AF dengan kuesioner aktivitas fisik anak, LP dengan pita standar dan TLB dengan bodyfat analyzer. Odd risk/OR $(95 \% \mathrm{CI})$ dan uji beda sebagai uji statistik, signifikan jika $(\mathrm{p}<0,05)$. Hasil menunjukkan anak dengan AF ringan, konsumsi gorengan ( $\geq 3 \mathrm{x} / \mathrm{minggu}$ ), dan minuman bergula ( $\geq 3 \mathrm{x} / \mathrm{minggu}$ ) berisiko 2,5 (95\% CI 1,19-5,39), 6,8 (CI 2,82-16,52), dan 10,7 (CI 4,46-25,72) kali mengalami overweight, secara berturut, dibanding anak dengan AF sedang, konsumsi gorengan dan minuman gula tinggi (masing-masing $<3 \mathrm{x}$ /minggu). Ada perbedaan yang signifikan antara kelompok overweight dibanding beratnormal berdasarkan asupan energi dan zat gizi makro, LP dan TLB. Perlu ditekankan pola makan dan pola hidup sehat untuk menghindari dampak negatif overweight di masa depan.
\end{abstract}

Kata kunci: fast food, IMT, lemak tubuh, lingkar pinggang, soft drink

\begin{abstract}
The prevalence of overweight children aged 5-12 years in Jakarta province is the highest $(30.1 \%$, national is 10.8\%). This study aims (1.) to analyze the relationship among fast food, soft drink, and physical activity (PA) with overweight status and (2.) to know the difference of intake, waist circumference (WC), and total body fat (TBF) in primary school children. This cross sectional study was conducted with a number of respondents consisting of 57 overweight and 57 normal weight children in public primary schools in Jakarta. The consumption of fast food and soft drink was measured using food frequency questionnaire, energy and macro nutrient intake by using three non-consecutive day recall method, PA by using physical activity questionnaire, WC by using standard tape, and TBF by using bodyfat analyzer. Odd risk/OR $(95 \%$ CI) and different test were used as statistical test with $p<0.05$. The results showed that children with low $P A, \geq 3 x /$ week fritter consumption, and $\geq 3 x /$ week sugary drinks were at risk 2.5 times (95\% CI 1.19-5.39), 6.8 times (CI 2.82 -16.52), and 10.7 times (CI 4.46-25.72) to overweight, respectively, compared with children with moderate $P A,<3 x /$ week fritter consumption, and $<3 x /$ week high sugar drink. There were
\end{abstract}


significant differences between the overweight group compared with the normal weight based on energy and macro nutrient intake, WC, and TBF. Diet and healthy lifestyle should be emphasized to avoid negative impact of overweight in the future.

Keywords: fast food, body mass index, body fat, waist circumference, soft drink

\section{PENDAHULUAN}

Kegemukan atau overweight saat ini merupakan epidemik global dan terjadi pada semua kelompok umur, termasuk anak-anak baik di negara maju maupun berkembang. Di Amerika, 1 dari 5 anak sekolah usia 6-19 tahun mengalami obesitas [1]. Di negara berkembang, diperkirakan 35 juta anak menderita kegemukan [2]. Di Indonesia, hasil Riskesdas 2013, menunjukkan kegemukan pada anak umur 5-12 tahun masih tinggi yaitu $18,8 \%$, terdiri dari gemuk $10,8 \%$ dan sangat gemuk (obesitas) $8,8 \%$. Prevalensi gemuk terendah di Nusa Tenggara Timur $(8,7 \%)$ dan tertinggi di DKI Jakarta $(30,1 \%)$ [3]. Studi tahun 2015 pada anak (kelas 1-6) di Jakarta Timur menunjukkan sebanyak $66 \%$ memiliki berat badan lebih dan $4 \%$ obesitas [4].

Masalah gizi lebih terjadi bersama-an dengan kemajuan ekonomi pada lapisan masyarakat tertentu, seperti ma-syarakat di daerah perkotaan [5]. Pola makan yang salah mudah menyebabkan kelebihan masukan energi yang dapat menimbulkan kegemukan bahkan gizi lebih. Kebiasaan konsumsi fast food dapat meningkatkan terjadinya prevalensi ke-gemukan pada anak-anak [4]. Daya beli masyarakat yang meningkat berdampak pula kepada sikap orang tua yang memanjakan anak-anaknya dalam hal pemberian makanan, khususnya makanan cepat saji (fast food) dan minuman ringan (soft drink) [6]. Penelitian pada 60 anak SD di Manado menunjukkan bahwa siswa yang mengonsumsi fast food lebih dari 3 kali per minggu mempunyai risiko 3,28 kali lebih besar menjadi gizi lebih dibandingkan dengan yang jarang (1-2 kali per minggu) konsumsi fast food [7]. Terkait soft drink, konsumsi harian anak- anak laki-laki di Amerika Serikat rata-rata hampir dua kaleng standar $(24 \mathrm{oz} / 700 \mathrm{ml})$ dan lebih dari satu kaleng standar untuk anak perempuan $(12 \mathrm{oz} / 350 \mathrm{ml})$ [8], bahkan pada remajanya mencapai empat sajian per hari [9]. Di Indonesia, konsumsi soft drink pada tahun 2010 mencapai 2,4 liter per minggunya [10].

Kurangnya aktivitas fisik memberikan pengaruh besar terhadap kegemukan karena berperan penting dalam pengaturan sistem tubuh dan penurunan risiko penyakit lain yang disebabkan oleh gizi lebih [11]. Asupan energi yang besar pada anak-anak yang mengonsumsi fast food dan soft drink dalam jumlah yang banyak tanpa diimbangi dengan aktivitas fisik yang cukup dapat menyebabkan terjadinya kegemukan [12]. Masa anakanak adalah masa pertumbuhan dan perkembangan sehingga kegemukan pada masa anak menyebabkan semakin banyaknya jumlah sel otot dan tulang rangka, sedangkan kegemukan pada orang dewasa hanya terjadi pembesaran sel-sel saja sehingga kemungkinan penurunan berat badan ke normal akan lebih mudah [13]. Anak yang mengalami kegemukan akan berisiko tinggi menderita kegemukan pada masa dewasa dan berpotensi mengalami berbagai penyebab kesakitan dan kemati-an antara lain penyakit kardiovaskular dan diabetes melitus serta akibat yang ditimbulkan kegemukan ini akan mem-punyai dampak terhadap tumbuh kembang anak itu sendiri [14]. Studi menunjukkan anak yang gemuk berisiko rendah prestasi akademik dan di masa dewasa berpotensi mengalami penyakit kronis (penyakit kardiovaskular diabetes tipe 2, gangguan ginjal) [12], beberapa jenis kanker $[15,16]$ sehingga berpotensi tinggi pada kematian [17]. 
Persen lemak tubuh di atas $35 \%$ pada anak laki-laki dan $25 \%$ pada anak perempuan merupakan faktor risiko PJK [18]. Berdasarkan uraian di atas aktivitas fisik, konsumsi fast food dan soft drink merupakan faktor yang memengaruhi status gizi lebih terutama pada anak usia sekolah. Penelitian sebelumnya tidak menilai total lemak tubuh atau ukuran antropometri lain misalnya lingkar pinggang yang mampu menjadi indikator obesitas sentral sehingga penelitian ini juga bertujuan untuk melihat perbedaan ukuran antropometri tersebut pada anak usia sekolah.

\section{METODE PENELITIAN \\ Rancangan/Desain Penelitian}

Penelitian ini menggunakan desain potong lintang dengan variabel independen utama ialah konsumsi fast food, soft drink, dan aktivitas fisik, sedangkan variabel dependen utama ialah kejadian overweight/kegemukan. Penelitian ini telah mendapat persetujuan fakultas dengan no. 129/DKN/GIZI/FIKES/ESA UNGGUL/III/2016.

\section{Sumber Data}

Data primer penelitian didapat dengan melakukan penilaian diet dengan kuesi-oner frekuensi makanan dan food recall 24 jam, penilaian aktivitas fisik dengan kuesioner aktivitas fisik terstandar, dan pengukuran antropometri secara langsung dengan melibatkan personil terlatih. Data lain terkait usia, kebiasaan sarapan, dan uang jajan dikumpulkan dengan kuesioner terstruktur.

\section{Sasaran Penelitian}

Populasi pada penelitian ini ialah siswa-siswi SDN 01 Kebon Jeruk kelas 4 dan 5 yang berjumlah 120 orang. Pemilihan sampel dilakukan dengan secara Kuota Sampling dengan mempertimbangkan kriteria inklusi dan ekslusi. Kriteria inklusi sebagai berikut: (i) siswa dengan status gizi lebih dan normal berdasarkan Indeks Massa Tubuh berdasarkan umur (IMT/U), (ii) tercatat aktif sebagai siswa sekolah, (iii) bersedia menjadi sample (informed consent pada orang tua), dan (iv) hadir saat penelitian. Ekslusi jika saat pengukuran dalam keadaan sakit atau ada kelainan bentuk tubuh atau disabilitas. Perhitungan sampel dengan rumus dua proporsi [19] berdasarkan penelitian Olyvia dkk. [20] untuk fastfood-status gizi, Ali dkk. [21] untuk aktivitas fisik-status gizi, dan Rahmadya [22] untuk softdrink-status gizi, dengan kekuatan uji statistik 90\% dan tingkat kepercayaan $95 \%$ serta nonrespondent rate $10 \%$ maka didapatkan sampel sebesar 57 masing-masing untuk siswa status gizi lebih dan status gizi normal (IMT/U).

\section{Pengembangan Instrument dan Teknik Pengumpulan Data}

Penilaian fastfood dan softdrink dilakukan dengan kuesioner frekuensi makanan (KFM) dengan rentang waktu satu bulan terakhir. Pilihan frekuensi yang tersedia ialah lebih dari $1 \mathrm{x} / \mathrm{hari}, 1 \mathrm{x} / \mathrm{hari}$, $6 \mathrm{x} /$ minggu, $5 \mathrm{x} / \mathrm{minggu}, \quad 4 \mathrm{x} /$ minggu, $3 \mathrm{x} /$ minggu, $2 \mathrm{x} /$ minggu, $1 \mathrm{x}$ minggu, 2 minggu sekali, sebulan sekali, dan tidak pernah. KFM dibuat dengan terlebih dahulu mendapatkan daftar bahan makanan melalui recall 24 jam pada 30 sampel lain yang tidak dimasukkan pada sampel. Survei makanan jajanan di sekolah pun dilakukan. Selain KFM, dilakukan pula food recall 24 jam selama 3 (tiga) hari tidak berturut. Aktifitas fisik diukur dengan kuesioner khusus untuk anak-anak yang terbagi menjadi kegiatan fisik dan pekerjaan rumah tangga, transportasi, olahraga dan bermain, waktu menghabiskan untuk duduk, waktu untuk istirahat, dan jam tidur. Pengukuran antropometri meliputi berat dan total lemak tubuh dengan menggunakan body fat analyzer merk Kris, tinggi badan dengan microtoise, dan lingkar pinggang 
dengan menggunakan tali meteran standar.

\section{Teknik Analisis Data}

Data asupan dianalisis dengan bantuan microsoft excel 2007 dan software Nutrisurvey. Data asupan kemudian diekspor ke software SPSS bersama dengan data lainnya untuk dilakukan analisis.

Data disajikan deskriptif seperti frekuensi dan persen $(n, \%)$ serta berdasar- kan distribusi data. Data terdistribusi normal (menurut uji KolmogorovSmirnov, normal jika $\mathrm{p}>0,05$ ) disajikan sebagai rerata \pm standar deviasi sebaliknya jika tidak normal disajikan sebagai median dan jarak antar kuartil (Q2-Q3). Uji bivariat dilakukan dengan chi-square, selain itu dihasilkan juga nilai OR (odds ratio) dengan $95 \%$ CI (confidence interval). Uji beda sesuai distribusi data pun dilakukan.

Tabel 1. Karakteristik Responden ${ }^{1}(\mathrm{~N}=114)$

\begin{tabular}{lccc}
\hline Variabel & Semua $(\mathbf{N}=114)$ & Overweight $(\mathbf{N}=\mathbf{5 7})$ & Normal $(\mathbf{N}=\mathbf{5 7})$ \\
\hline Usia, tahun & $11(10-11)^{2}$ & $11(10,5 ; 11)^{2}$ & $11(10 ; 11)^{2}$ \\
Anak laki-laki & $54(47,4)$ & $38(70,4)$ & $16(29,6)$ \\
Uang jajan, Rp/hari & $10,000(5000-$ & $10,000(5000 ;$ & $10,000(6000 ; 12,000)^{2}$ \\
& $12,000)^{2}$ & $11,000)^{2}$ & \\
Kebiasaan sarapan, ya & $108(94,7)$ & $53(49,1)$ & $55(50,9)$ \\
Makan utama $\geq 3, x /$ hari & $77(67,5)$ & $34(47,2)$ & $38(52,8)$ \\
\hline${ }^{1}$ Semua nilai dinyatakan sebagai & $\mathrm{n}(\%)$, kecuali diindikasikan lain; ${ }^{2}$ Median dan jarak antar kuartil $\left(Q_{25}\right.$ \\
$\left.Q_{75}\right),{ }^{3}$ Gemuk jika IMT/U $>1$. & &
\end{tabular}

Tabel 2. Perbedaan Asupan Energi dan Zat Gizi Harian Antara Anak dengan Status Gizi Lebih dan Normal ${ }^{1}$

\begin{tabular}{|c|c|c|c|}
\hline Variabel & Overweight $(\mathrm{N}=57)$ & Normal $(\mathrm{N}=57)$ & p-value \\
\hline Energi, kkal/hr & $1962(1874 ; 2089)^{2}$ & $1549(1453 ; 1580)^{2}$ & $0,001 * 3$ \\
\hline Protein, $g / h r$ & $69,38 \pm 10,17$ & $57,94 \pm 11,11$ & $0,001 * 4,5$ \\
\hline \%energi & $15,3 \pm 2,9$ & $14,0 \pm 1,8$ & \\
\hline Lemak, $g / h r$ & $76,35 \pm 9,70$ & $59,27 \pm 12,11$ & $0,001 * 4,5$ \\
\hline \%energi & $35,0 \pm 5,8$ & $34,7 \pm 3,8$ & \\
\hline Karbohidrat, $g / h r$ & $257,08 \pm 24,12$ & $194,40 \pm 27,70$ & $0,001 * 4,5$ \\
\hline \%energi & $51,3 \pm 6,8$ & $51,9 \pm 3,6$ & \\
\hline
\end{tabular}


Tabel 3. Status Gizi Anak Berdasarkan Indeks Massa Tubuh-Umur (IMT/U), Persen Lemak Tubuh, dan Lingkar Pinggang ${ }^{1}$ ( $\left.=114\right)$

\begin{tabular}{lccc}
\hline Variabel & Overweight $(\mathbf{N}=\mathbf{5 7})$ & Normal $(\mathbf{N}=\mathbf{5 7})$ & p-value \\
\hline IMT/u, $z$-score & $1,82(1,46 ; 2,07)^{5}$ & $-0,21(-0,80 ; 0,58)^{5}$ & $0,000^{6}$ \\
Normal & $0(0,0)$ & $57(100)$ & \\
Gemuk & $41(100)$ & - & \\
Obes & $16(100)$ & - & \\
Total lemak tubuh ${ }^{2}, \%$ & $25,02 \pm 7,11^{4}$ & $11,24 \pm 4,62^{4}$ & $0,000^{* 7,8}$ \\
$\quad$ Lemak kurang & 0 & $42(100)$ & \\
Normal & $25(62,5)$ & $15(37,5)$ & \\
Kelebihan lemak & $21(100)$ & $0(0,0)$ & \\
Obes & $11(100)$ & $0(0,0)$ & \\
Lingkar pinggang ${ }^{3}, c m$ & $81(72,5 ; 88)^{5}$ & $61(58 ; 65,5)^{5}$ & $0,000^{* 6}$ \\
Lemak visceral rendah & $12(17,6)$ & $56(82,4)$ & \\
Lemak visceral tinggi & $45(97,8)$ & $1(2,2)$ & \\
\hline
\end{tabular}

${ }^{1}$ Semua nilai dinyatakan sebagai n (\%), kecuali diindikasikan lain; ${ }^{2}$ Diukur dengan Body Fat Analyzer merk Kris; ${ }^{3}$ Diukur dengan pita standar dengan mengambil titik tengah horizontal antara panggul atas dan dasar rusuk (rib); ${ }^{4} \mathrm{Mean} \pm \mathrm{SD}$ (standard deviation); ${ }^{5}$ Median dan jarak antar kuartil $\left(\mathrm{Q}_{25} ; \mathrm{Q}_{75}\right) ;{ }^{6}$ MannWhitney test $;{ }^{7}$ Independent t-test;

${ }^{8}$ Equal variances not assumed; *signifikan jika $\mathrm{p}<0,05$

Tabel 4. Hubungan Jenis Kelamin, Aktifitas Fisik, dan Status Gizi Anak Sekolah ${ }^{1}$ $(\mathrm{N}=114)$

\begin{tabular}{lcccc}
\hline Variabel & $\begin{array}{c}\text { Overweight } \\
(\mathbf{N}=\mathbf{5 7})\end{array}$ & Normal $(\mathbf{N = 5 7 )}$ & OR (95\%CI) & p-value \\
\hline Jenis Kelamin & $38(70,4)$ & $16(29,6)$ & $5,12(2,31-11,39)$ & $0,000^{*}$ \\
$\quad$ Laki-laki & $19(31,7)$ & $41(68,3)$ & & \\
$\quad \begin{array}{l}\text { Perempuan } \\
\text { Tingkat aktifitas fisik }\end{array}$ & $34(61,8)$ & $21(38,2)$ & $2,53(1,19-5,39)$ & $0,025^{*}$ \\
$\quad$ Ringan & & & & \\
$\begin{array}{l}(1,40 \leq \mathrm{PAL} \leq 1,69) \\
\quad \text { Sedang }\end{array}$ & $23(39,0)$ & $36(61,0)$ & & \\
$(1,70 \leq \mathrm{PAL} \leq 1,99)$ & & & & \\
\hline
\end{tabular}

${ }^{1}$ Semua nilai dinyatakan sebagai n (\%), kecuali diindikasikan lain; ${ }^{2}$ Chi- square test; $*$ signifikan jika $\mathrm{p}<0.05$ 
Tabel 5. Faktor Risiko Kegemukan pada Anak Sekolah Berdasarkan Frekuensi Asupan Fast food dan Soft drink ${ }^{1}(\mathrm{~N}=114)$

\begin{tabular}{|c|c|c|c|c|}
\hline Variabel & Overweight $(\mathrm{N}=57)$ & Normal $(\mathrm{N}=57)$ & OR (95\% CI) & p-value ${ }^{2}$ \\
\hline \multicolumn{5}{|c|}{ Energy-densed food } \\
\hline \multicolumn{5}{|l|}{ Fried Chicken } \\
\hline$\geq 3-7 \mathrm{x} /$ minggu & $38(76,0)$ & $12(24,0)$ & \multirow{2}{*}{$7,50(3,23-17,40)$} & \multirow{2}{*}{$0,000^{*}$} \\
\hline$<3 \mathrm{x} / \mathrm{minggu}$ & $19(29,7)$ & $45(70,3)$ & & \\
\hline \multicolumn{5}{|l|}{ Burger } \\
\hline 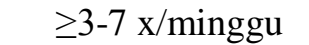 & $17(70,8)$ & $7(29,2)$ & \multirow{2}{*}{$3,04(1,15-8,04)$} & \multirow{2}{*}{$0,039^{*}$} \\
\hline$<3 \mathrm{x} /$ minggu & $40(44,4)$ & $50(55,6)$ & & \\
\hline \multicolumn{5}{|l|}{ Pizza } \\
\hline$\geq 3-7 x /$ minggu & $18(72,0)$ & $7(28,0)$ & \multirow{2}{*}{$3,29(1,25-8,68)$} & \multirow{2}{*}{$0,024 *$} \\
\hline$<3 \mathrm{x} /$ minggu & $39(43,8)$ & $50(56,2)$ & & \\
\hline \multicolumn{5}{|l|}{ Spaghetti } \\
\hline$\geq 3-7 \mathrm{x} / \mathrm{minggu}$ & $46(69,7)$ & $20(30,3)$ & \multirow{2}{*}{$\begin{array}{c}7,74 \\
18,17)\end{array}$} & \multirow{2}{*}{$\begin{array}{l}0,000 \\
*\end{array}$} \\
\hline$<3 \mathrm{x} / \mathrm{minggu}$ & $11(22,9)$ & $37(77,1)$ & & \\
\hline \multicolumn{5}{|l|}{ French fries } \\
\hline$\geq 3-7 \mathrm{x} / \mathrm{minggu}$ & $44(67,7)$ & $21(32,3)$ & \multirow[t]{2}{*}{$5,80(2,55-13,17)$} & \multirow[t]{2}{*}{$0,000^{*}$} \\
\hline$<3$ x/minggu & $13(26,5)$ & $36(73,5)$ & & \\
\hline \multicolumn{5}{|l|}{ Sausage } \\
\hline$\geq 3-7 \mathrm{x} / \mathrm{minggu}$ & $45(73,8)$ & $16(26,2)$ & \multirow[t]{2}{*}{$9,61(4,06-22,70)$} & \multirow[t]{2}{*}{$0,000^{*}$} \\
\hline$<3 \mathrm{x} / \mathrm{minggu}$ & $12(22,6)$ & $41(77,4)$ & & \\
\hline \multicolumn{5}{|l|}{ Nugget } \\
\hline$\geq 3-7 \mathrm{x} / \mathrm{minggu}$ & $40(76,9)$ & $12(23,1)$ & \multirow[t]{2}{*}{$8,82(3,76-20,71)$} & \multirow[t]{2}{*}{$0,000^{*}$} \\
\hline$<3 \mathrm{x} /$ minggu & $17(27,4)$ & $45(72,6)$ & & \\
\hline \multicolumn{5}{|l|}{ Meatball } \\
\hline$\geq 3-7 \mathrm{x} / \mathrm{minggu}$ & $31(68,9)$ & $14(31,1)$ & \multirow[t]{2}{*}{$3,66(1,65-8,13)$} & \multirow[t]{2}{*}{$0,002 *$} \\
\hline$<3 \mathrm{x} /$ minggu & $26(37,7)$ & $43(62,3)$ & & \\
\hline \multicolumn{5}{|l|}{ Instant noodle } \\
\hline$\geq 3-7 \mathrm{x} / \mathrm{minggu}$ & $31(79,5)$ & $8(20,5)$ & $7,3092,94-18,16)$ & $0,000 *$ \\
\hline$<3 \mathrm{x} /$ minggu & $26(34,7)$ & $49(65,3)$ & & \\
\hline Fried foods & & & & \\
\hline$\geq 3-7 \mathrm{x} / \mathrm{minggu}$ & $48(65,8)$ & $25(34,2)$ & $6,83(2,82-16,52)$ & $0,000 *$ \\
\hline$<3 \mathrm{x} / \mathrm{minggu}$ & $9(22,0)$ & $32(78,0)$ & & \\
\hline Energy-densed drin & & & & \\
\hline Bottle sweet tea & & & & \\
\hline z3-7 x/minggu & $29(67,4)$ & $14(32,6)$ & $3,18(1,44-7,05)$ & $0,007 *$ \\
\hline$<3 \mathrm{x} / \mathrm{minggu}$ & $28(39,4)$ & $43(60,6)$ & & \\
\hline Instant powder drin & & & & \\
\hline$\geq 3-7 \mathrm{x} / \mathrm{minggu}$ & $46(74,2)$ & $16(25,8)$ & $5,55(2,48-12,40)$ & $0,000 *$ \\
\hline$<3 \mathrm{x} /$ minggu & $11(21,2)$ & $41(78,8)$ & & \\
\hline Carbonated-drinks & & & & \\
\hline$\geq 3-7 \mathrm{x} / \mathrm{minggu}$ & $17(70,8)$ & $7(29,2)$ & $3,04(1,15-8,04)$ & $0,039 *$ \\
\hline$<3 \mathrm{x} /$ minggu & $40(44,4)$ & $50(55,6)$ & & \\
\hline
\end{tabular}

\section{HASIL PENELITIAN}

Sampel rata-rata berusia 11 tahun dan lebih dari setengahnya siswa perempuan $(52,6 \%)$. Uang jajan sampel sama antara kelompok status gizi gemuk dan normal.
Lebih dari setengah sampel dengan status gizi normal biasa sarapan dan memiliki kebiasan makan utama $\geq 3 \times$ tiap harinya (Tabel 1). Konsumsi energi, protein, lemak, dan karbohidrat pada kelompok 
status gizi gemuk secara bermakna berbeda dibandingkan dengan kelompok normal (Tabel 2). Tabel 3 menunjukkan perbedaan yang bermakna antara indikator IMT/U, total lemak tubuh, dan lingkar pinggang antara siswa dengan status gizi gemuk dan normal. Tabel 4 menyajikan adanya hubungan bermakna antara jenis kelamin dengan status gizi berdasarkan IMT/U, dimana laki-laki lebih banyak yang memiliki status gizi gemuk dibandingkan perempuan. Begitu juga dengan aktifitas fisik, siswa yang memiliki aktifitas fisik 24 jam dalam kategori ringan lebih banyak pada siswa dengan status gizi gemuk.

\section{PEMBAHASAN}

Temuan utama penelitian ini menunjukkan adanya hubungan konsumsi makanan tinggi energi (fast food, soft drink) dan rendahnya aktifitas fisik dengan kegemukan pada siswa. Temuan ini sejalan dengan penelitian [5,7] yang menyatakan bahwa terdapat hubungan yang bermakna antara kebiasaan makan fast food dengan kejadian gizi lebih. Begitu pula kaitan konsumsi soft drink dengan kegemukan siswa, sebuah systematic review menunjukkan meningkatnya risiko kegemukan pada anak-anak yang sering konsumsi softdrink [23]. Berdasarkan pengamatan di kantin sekolah selama penelitian ini, sebagian besar makanan yang tersedia mengandung tinggi energi, lemak, dan rendah serat serta minuman tinggi gula (Tabel 5). Temuan pada konsumsi pangan ini, sejalan juga dengan data asupan energi dan zat gizi makro (Tabel 2) yang menunjukkan asupan energi, protein, lemak, dan karbohidrat yang lebih tinggi pada siswa dengan status overweight dibandingkan dengan siswa status gizi normal.

Kegemukan terjadi akibat ketidakseimbangan antara konsumsi dengan pengeluaran energi selama jangka panjang [12]. Fast food dan soft drink dikenal sebagai makanan tinggi energi, tinggi lemak dan gula serta rendah serat sehingga berkaitan dengan bertambahnya simpanan lemak tubuh karena ketidakseimbangan asupan dan pengeluaran energi [12,24]. Bahkan konsumsi softdrink saja dapat meningkatkan rasa lapar dan menurunkan asupan buah dan sayur [23]. Sebenarnya, bukan hanya konsumsi fast food dan soft drink, makanan lain pun seperti tinggi karbohidrat dan protein dapat menyebabkan kegemukan. Bedanya, kelebihan asupan karbohidrat akan dimetabolisme oleh tubuh menjadi cadangan lemak melalui proses de novo lipogenesis $[25,26]$. Sebaliknya kelebihan protein juga dapat meningkatkan massa tubuh tetapi bukan lemak [27, 28]. Walaupun begitu dengan penggunaan indikator indeks massa tubuh (IMT), kenaikan massa tubuh akibat lemak (fat mass) maupun kenaikan massa tubuh bukan lemak (fat free mass), tidak dibedakan karena IMT bukan indictor yang cocok untuk menggambarkan komposisi tubuh.

Terkait aktifitas fisik, penelitian menemukan sebagian besar siswa dengan status gizi lebih memiliki aktifitas fisik yang ringan atau rendah (Tabel 4). Anak yang memiliki aktivitas fisik ringan berisiko 2,5 kali mengalami kegemukan daripada anak yang memiliki aktivitas fisik sedang. Studi case-control di Bangladesh menemukan peningkatan 60 persen risiko kegemukan bagi anak yang tidak meluangkan aktifitas fisik rutin di rumah [29]. Temuan ini juga sejalan dengan penelitian lain di Indonesia [5,30,31,32] bahwa adanya hubungan yang signifikan antara rendah aktivitas fisik dengan kejadian kegemukan. Kurang aktifitas fisik berarti kurang pengeluaran energi sehingga tubuh melakukan penyimpanan kelebihan energi dalam bentuk lemak. Hal ini dapat dijelaskan secara fisiologi, pengeluaran energi (energy expenditure) yang kurang menyebabkan zat gizi (terutama karbohidrat) yang sedianya untuk produksi energi sel 
menjadi produksi lemak yang disimpan pada jaringan adiposit [26].

Aktifitas yang rendah pada siswa dapat berkaitan dengan perubahan gaya hidup anak yang dramatis, seperti banyaknya permainan elektronik pada handphone yang menggantikan permainan aktif seperti bermain bola pada anak dan penggunaan kendaraan bermotor untuk aktifitas dengan jarak tempuh jauh yang sebelumnya ditempuh dengan berjalan, berlari atau bersepeda [33]. Secara detail, aktivitas fisik yang sering dilakukan responden pada penelitian ini sebagian besar ialah bermain game online atau gadget $(39,5 \%)$ dan menonton televisi $(42,1 \%)$ yang tidak begitu banyak mengeluarkan energi. Selain itu, mereka mendapakan jemputan dengan kendaraan bermotor setiap berangkat maupun pulang sekolah sehingga energi yang mereka keluarkan tidak sesuai dengan asupan makanan mereka, sehingga berakibat kelebihan energi dalam tubuh (data tidak disajikan).

Temuan lain penelitian ini ialah, tingginya persen lemak tubuh dengan kategori lemak overfat dan obese pada siswa dengan status gizi lebih (Tabel 3). Hal ini menunjukkan bahwa siswa yang memiliki status gizi lebih akan memiliki persen lemak tubuh yang cenderung tinggi, sedangkan status gizi normal akan cenderung memiliki persen lemak tubuh normal ataupun underfat. Penelitian Rahmawati [34] juga menemukan perbedaan persen lemak tubuh antara kelompok gizi lebih dan gizi normal. Hal ini menegaskan bahwa semakin tinggi IMT maka semakin tinggi pula persen lemak tubuh [35]. Tetapi walaupun begitu, IMT belum dapat menggambarkan jumlah dan distribusi lemak dalam tubuh [36]. Seseorang dengan IMT tinggi belum tentu kelebihan lemak, karena yang bertambah bukan lemak melainkan lean body mass atau otot, namun ada juga IMT normal tetapi memiliki lemak tubuhnya tinggi [37]. Selain berdasarkan total lemak tubuh, penelitian ini juga melihat distribusi lemak tubuh dengan menggunakan lingkar pinggang sebagai indikator lemak visceral atau perut. Hasil penelitian menunjukkan bahwa siswa dengan status gizi gemuk memiliki lemak visceral lebih tinggi dibandingkan siswa dengan status gizi normal (Tabel 3). Bertambahnya lingkar pinggang dapat menjadi perhatian bagi kesehatan siswa di masa yang akan datang karena berkaitan dengan tingginya risiko menderita berbagai macam penyakit saat dewasa seperti diabetes mellitus. Kelebihan dari pengukuran lingkar pinggang ialah adanya informasi distribusi lemak yang tidak dapat disajikan oleh pengukuran IMT [11]. IMT tidak dapat membedakan antara berat yang berhubungan dengan otot dan lemak. Lingkar pinggang perut lebih akurat untuk mencerminkan obesitas sentral [38]. Walau begitu, IMT dan lingkar pinggang tidak dapat berdiri sendiri sebagai indikator obesitas yang dapat memicu penyakit degeneratif [39].

Berdasarkan penelitian ini, perlu adanya edukasi tentang pola makan yang seimbang dan aktifitas fisik yang aktif pada siswa. Edukasi ini perlu karena sesuai dengan karakteristiknya, anak usia sekolah memilih jenis makanan didasarkan pada rasa suka dan tidak suka serta pengaruh lingkungannya [40-42]. Membawa bekal ke sekolah dapat juga menjadi salah satu cara mengurangi konsumsi fast food dan soft drink pada siswa sekolah $[4,43,44]$. Peningkatan aktifitas fisik berupa permainan luar ruangan perlu ditingkatkan lagi baik di sekolah maupun di rumah. Orang tua dan guru sebaiknya dapat mencontohkan melakukan aktifitas fisik yang aktif.

\section{SIMPULAN}

Konsumsi fast food dan softdrink serta rendahnya aktifitas fisik berhubungan positif dengan status kegemukan pada siswa. Kegemukan (overweight) pada siswa juga terlihat sejalan dengan 
total lemak tubuh dan tumpukan lemak pada perut (visceral).

\section{UCAPAN TERIMA KASIH}

Terimakasih kami sampaikan pada guru dan siswa/i sekolah serta orang tua yang sudah berkenan mendukung terlaksananya penelitian ini.

\section{KONFLIK KEPENTINGAN}

Tidak adanya konflik kepentingan antar penulis.

\section{DAFTAR RUJUKAN}

1. Ogden CL, Carroll MD, Lawman HG, Fryar CD, Kruszon-Moran D, Kit BK, et al. Trends in Obesity Prevalence Among Children and Adolescents in The United States, 1988-1994 through 2013-2014. Jama. 2016; 315 (21): 2292-9.

2. De Onis M, Blössner M, Borghi E. Global Prevalence and Trends of Overweight and Obesity Among Preschool Children. Am J Clin Nutr. 2010; 92 (5): 1257-64.

3. Kementerian Kesehatan RI. Riset Kesehatan Dasar. Jakarta Kementerian Kesehatan RI. 2013.

4. Octaviana SP. Faktor-faktor yang berhubungan dengan Status Gizi Lebih pada Siswa Sekolah Dasar Negeri 05 Kuningan Barat di Kecamatan Mampang Prapatan Tahun 2013. 2015.

5. Setyowati YD. Hubungan Antara Aktivitas Fisik, Konsumsi Fast Food, dan Soft Drink pada Anak Obesitas di Usia Sekolah Dasar. 2014.

6. Do Wendt MH. Economic, Environmental, and Endowment Effects on Childhood Obesity and School Performance. 2009.

7. Badjeber F, Kapantouw NH, Punuh M. Konsumsi Fast Food sebagai Faktor Risiko Terjadinya Gizi Lebih pada Siswa SD Negeri 11 Manado. KESMAS. 2012; 1 (1): 11-14.
8. French SA, Story M, NeumarkSztainer D, Fulkerson JA, Hannan P. Fast Food Restaurant Use Among Adolescents: Associations with Nutrient Intake, Food Choices, and Behavioral And Psychosocial Variables. Int J Obes. 2001; 25 (12): 1823.

9. Committee on School Health. Soft Drinks in Schools. Pediatrics. 2004; 113 (1): 152-4.

10. Kementerian Kesehatan RI. Riset Kesehatan Dasar. Jakarta Kementerian Kesehatan RI. 2010.

11. Klein S, Allison DB, Heymsfield SB, Kelley DE, Leibel RL, Nonas C, et al. Waist Circumference and Cardiometabolic Risk: A Consensus Statement from Shaping America's Health: Association for Weight Management and Obesity Prevention; NAASO, The Obesity Society; The American Society for Nutrition; and The American Diabetes Association. Obesity. 2007; 15 (5): 1061-7.

12. Sahoo K, Sahoo B, Choudhury AK, Sofi NY, Kumar R, Bhadoria AS. Childhood obesity: Causes and Consequences. J Fam Med Prim Care. 2015; 4 (2): 187.

13. Frederick CB, Snellman K, Putnam RD. Increasing Socioeconomic Disparities in Adolescent Obesity. Proc Natl Acad Sci. 2014; 111 (4): 1338-42.

14. Puhl RM, Luedicke J. Weight-based Victimization Among Adolescents in The School Setting: Emotional Reactions and Coping Behaviors. J Youth Adolesc. 2012; 41 (1): 27-40.

15. Campbell PT. Obesity: A Certain and Avoidable Cause Of Cancer. The Lancet. 2014; 384 (9945): 727-8.

16. De Pergola G, Silvestris F. Obesity as A Major Risk Factor for Cancer. $\mathbf{J}$ Obes. 2013; 2013.

17. Flegal KM, Kit BK, Orpana H, Graubard BI. Association of All- 
Cause Mortality with Overweight and Obesity UsingStandard Body Mass Index Categories: A Systematic Review And MetaAnalysis. Jama. 2013; 309 (1): 7182.

18. Wickramasinghe VP, Lamabadusuriya SP, Cleghorn GJ, Davies PS. Validity of Who BMI Charts for The Diagnosis of Obesity In Children of Two Different Ethnic Groups. In: KS. Karger AG; 2009. p. 103-103.

19. Lwanga SK, Lemeshow S. Sample size determination in health studies: a practical manual. Jenewa: World Health Organization; 1991.

20. Olyvia L, Garna H, Sedjati A. Hubungan Asupan Makanan dan Aktivitas Fisik dengan Kejadian Obesitas pada Anak Sekolah Dasar di Kota Bandung. 2015.

21. Ali Suandana IN, Sidiartha I. Hubungan Aktivitas Fisik dengan Obesitas pada Anak Sekolah Dasar. E-J Med Udayana. 2014; 3 (12).

22. Saputri R. Hubungan Antara Pengetahuan Soft Drink dan Konsumsi Soft Drink dengan Kejadian Obesitas pada Anak Usia Remaja di SMP Budi Mulia Dua Yogyakarta. 2013.

23. Vartanian LR, Schwartz MB, Brownell KD. Effects of Soft Drink Consumption on Nutrition and Health: A Systematic Review and Meta-Analysis. Am J Public Health. 2007; 97 (4): 667-675.

24. Stelmach-Mardas M, Rodacki T, Dobrowolska-Iwanek J, Brzozowska A, Walkowiak J, WojtanowskaKrosniak A, et al. Link Between Food Energy Density and Body Weight Changes In Obese Adults. Nutrients. 2016; 8 (4): 229.

25. Parks EJ. Effect of Dietary Carbohydrate on Triglyceride Metabolism in Humans. J Nutr. 2001; 131 (10): $2772 S$ - 2774S.
26. Minehira K, Vega N, Vidal $\mathrm{H}$, Acheson K, Tappy L. Effect of Carbohydrate Overfeeding on Whole Body Macronutrient Metabolism and Expression of Lipogenic Enzymes in Adipose Tissue of Lean And Overweight Humans. Int $\mathrm{J}$ Obes. 2004; 28 (10): 1291-8.

27. Farham B. Effect of Dietary Protein Content on Weight Gain, Energy Expenditure, and Body Composition During Overeating. Contin Med Educ. 2012; 30 (2): 81.

28. Johnston CS, Tjonn SL, Swan PD. High-protein, Low-Fat Diets are Effective for Weight Loss and Favorably Alter Biomarkers in Healthy Adults. J Nutr. 2004; 134 (3): 586-91.

29. Bhuiyan MU, Zaman S, Ahmed T. Risk Factors Associated with Overweight and Obesity Among Urban School Children and Adolescents in Bangladesh: A CaseControl Study. BMC Pediatr. 2013; 13 (1): 72.

30. Danari AL, Mayulu N, Onibala F. Hubungan Aktivitas Fisik dengan Kejadian Obesitas pada Anak SD di Kota Manado. J Keperawatan. 2013; 1 (1).

31. Widyawati N. Faktor-Faktor yang Berhubungan dengan Obesitas pada Anak Sekolah Dasar Usia 6-14 Tahun di SD Budi Mulia 2 Yoyakarta Tahun 2014. 2015.

32. Handayani M, Utomo NWB. Faktor-faktor yang Berhubungan dengan Obesitas Pada Anak Usia 612 Tahun di Madrasah Ibtidaiyah Negeri Pondok Pinang Jakarta. 2014.

33. Endo JCRP. Prevalence and Correlates of Obesity in Schoolchildren from The City of Bursa, Turkey. J Clin Res Ped Endo. 2008; 1 (2): 80-8.

34. Rahmawati DD. Perbedaan Persen Lemak Tubuh, Konsumsi Lemak, Karbohidrat dan Air Pada Remaja 
Putri yang Overweight dan Non Overweight di Fakultas Ilmu Kesehatan UMS. 2014.

35. Katrina I. Kejadian Obesitas Berdasarkan Persen Lemak Tubuh dan Rasio Lingkar Pinggang Pinggul Serta Faktor-Faktor Lain yang Berhubungan Pada Prelansia dan Lansia Kelurahan Depok Jaya. Depok: Fakultas Kesehatan Masyarakat, Universitas Indonesia; 2012.

36. Wannamethee SG, Shaper AG, Whincup PH. Body Fat Distribution, Body Composition, and Respiratory Function In Elderly Men. Am J Clin Nutr. 2005; 82 (5): 996-1003.

37. Gallagher D, Heymsfield SB, Heo M, Jebb SA, Murgatroyd PR, Sakamoto Y. Healthy Percentage Body Fat Ranges: An Approach for Developing Guidelines Based on Body Mass Index. Am J Clin Nutr. 2000; 72 (3): 694-701.

38. Sönmez K, Akcakoyun M, Akcay A, Demir D, Duran N, Gencbay M, et al. Which Method Should Be Used to Determine The Obesity, in Patients with Coronary Artery Disease?(Body Mass Index, Waist Circumference or Waist-Hip Ratio). Int J Obes. 2003; 27 (3): 341-6.

39. Price GM, Uauy R, Breeze E, Bulpitt CJ, Fletcher AE. Weight, Shape, and
Mortality Risk in Older Persons: Elevated Waist-Hip Ratio, Not High Body Mass Index, is Associated with A Greater Risk of Death. Am J Clin Nutr. 2006; 84 (2): 449-60.

40. Sartika RAD. Penerapan Komunikasi, Informasi, dan Edukasi Gizi Terhadap Perilaku Sarapan Siswa Sekolah Dasar. Kesmas Natl Public Health J. 2012; 7 (2): 76-82.

41. Thasim S, Syam A, Najamuddin U. Pengaruh Edukasi Gizi Terhadap Perubahan Pengetahuan dan Asupan Zat Gizi pada Anak Gizi Lebih di SDN Sudirman I Makassar Tahun 2013. 2013.

42. Rostania M, Syam A, Najamuddin U. Pengaruh Edukasi Gizi Terhadap Perubahan Pengetahuan dan Gaya Hidup Sedentary Pada Anak Gizi Lebih di SDN Sudirman 1 Makassar Tahun 2013. 2013.

43. Angkasa D, Sitoayu L, Putri VR, Mulyadi M. Peduli Sarapan dan Makanan Sehat, Serta Higiene dan Sanitasi Lingungan Sekolah Pada Siswa Sekolah Dasar di Kecamatan Sepatan Timur. J Pengabdi Masy AbdiMas. 2017; 3 (2).

44. Meriska I, Pramudho K, Murwanto B. Perilaku Sarapan Pagi Anak Sekolah Dasar. J Kesehat. 2016; 5 (1). 